\title{
The Influence of Beauty Vloggers, Brand Image, and Product Quality on Lipstick Purchase Decisions
}

\author{
Helma Malini ${ }^{1 *}$ \\ ${ }^{1}$ Fakultas Ekonomi dan Bisnis, Universitas Tanjungpura, Pontianak, Kalimantan Barat-Indonesia \\ * corresponding author: malini@ekonomi.untan.ac.id
}

\begin{abstract}
Women place a high value on their appearance. We can see in everyday life that most women are unable to live without cosmetics. Cosmetics have become a necessity for women to support their appearance while going about their daily activities in order to make them more attractive and confident. Women's lipstick is one of the most popular cosmetics. Consumers consider brand image and product quality when purchasing cosmetics, particularly lipsticks. The goal of this study is to see if the image of Beauty Vloggers and the quality of their products have an impact on purchase decisions. The sample size for this study was 100 people. Explanatory research methods are used. Multiple linear regression analysis with IBM SPSS Statistics 25 was used to analyze the data. The findings of this study show that in Indonesia, Beauty Vlogger Brand Image has no significant impact on Emina Cosmetics Lipstick Product Purchase Decisions, while Product Quality has a significant impact on Emina Cosmetics Lipstick Product Purchase Decisions.
\end{abstract}

Keywords: beauty vlogger, brand image, product quality, purchase decision

Abstrak-Wanita menempatkan nilai tinggi pada penampilan mereka. Kita dapat melihat dalam kehidupan sehari-hari bahwa kebanyakan wanita tidak dapat hidup tanpa kosmetik. Kosmetik sudah menjadi kebutuhan bagi wanita untuk menunjang penampilan saat menjalani aktivitas sehari-hari agar lebih menarik dan percaya diri. Lipstik wanita adalah salah satu kosmetik paling populer. Konsumen mempertimbangkan citra merek dan kualitas produk saat membeli kosmetik, khususnya lipstik. Tujuan dari penelitian ini adalah untuk melihat apakah citra Beauty Vlogger dan kualitas produknya berpengaruh terhadap keputusan pembelian. Besar sampel untuk penelitian ini adalah 100 orang. Metode penelitian eksplanatori digunakan. Analisis regresi linier berganda dengan IBM SPSS Statistics 25 digunakan untuk menganalisis data. Temuan penelitian ini menunjukkan bahwa di Indonesia, Brand Image Beauty Vlogger tidak berpengaruh signifikan terhadap Keputusan Pembelian Produk Lipstik Emina Cosmetics, sedangkan Kualitas Produk berpengaruh signifikan terhadap Keputusan Pembelian Produk Lipstik Emina Cosmetics.

Kata kunci: beauty vloggre, citra merek, kualitas produk, keputusan membeli

\section{INTRODUCTION}

Women's cosmetics have progressed from a desire to a necessity for women who want to look attractive; in fact, every woman wants to look beautiful in every situation. Women put a lot of emphasis on their appearance. Most women are unable to function without the use of cosmetics, as evidenced by their daily lives. Women are willing to spend money on cosmetics in order to improve their self-esteem. Beauty product manufacturers compete to promote their products at prices that range from very low to quite high Saputri and Setyawati (2020) The numerous types of cosmetics circulating, both domestically and internationally produced, attested to this, according to the report. Cosmetics have become a necessity for women to maintain their appearance while going about their daily activities, making them more attractive and confident.

The purpose of lipstick is to give color to the lips and brighten the face. Lipstick comes in a variety of shapes and sizes. Lipcream is lipstick with a cream-like texture, while liptint is lipstick with a liquid texture. Entrepreneurs compete to market their products in a variety of ways in order to promote the lipsticks they sell. A research from (Laksmitasari \& Wandebori, 2017) showed that lipstick has been a basic need in woman cosmetics where woman purchase it on period and preferences basis The majority of people believe that marketing consists solely of selling and advertising.

Needs are a state of feeling deprived, whereas wants are human needs that are shaped by one's culture and personality. Desires are shaped by society, and these desires are then expressed in objects that can meet those needs. When purchasing power is added to the desire for resources, wants become demand. Humans expect a wide range of product features that help them achieve the highest level of satisfaction (Irtanti, 2019). The introduction of needs and desires, information seekers, evaluation of purchasing alternatives, purchase decisions, and behavior after purchase are all part of the purchasing decisions approach to 
solving problems in human activities to buy goods or services in order to fulfill their wants and needs (Dhestantya, Nesia, \& Restu, 2018). Marketing according to (Armstrong, Kotler, \& Da Silva, 2006) is a social process in which individuals and groups exchange values with one another in order to meet their needs. According to the various (Laksmitasari \& Wandebori, 2017), one of the most popular categories today, particularly among women, is beauty content. Beauty Vloggers, or content creators who specialize in sharing information about the world of beauty, arose as a result of this phenomenon.

The second factor that influences purchasing decisions is brand image (Hasmiati et al., 2020). Consumers' perceptions of a product or service are known as brand image. A good image has an impact on the price. The exchange rate of goods or services chosen by consumers is referred to as price. Purchasing decisions are made based on a combination of price, value, and quality perceptions. Product quality is the third factor that influences purchasing decisions, according to (Armstrong et al., 2006). Purchasing decisions are consumers' understanding of the wants and needs for a product by assessing existing sources by setting purchase goals and identifying alternatives so that decision makers to buy are accompanied by behavior after making a purchase. While, (Dhestantya et al., 2018) Put forward the purchase decision is the stage of decision assessment that causes buyers to form choices among several brands that are incorporated in the choice set and form an intention to buy.

Cosmetic companies' performance will be influenced by differences in a variety of factors and variables that influence a consumer's decision to purchase cosmetic products. As a result, research on related variables such as beauty vloggers, brand image, and purchasing decisions will not only help consumers make purchasing decisions, but will also help cosmetic companies position their products in consumers' minds.

\section{Theoretical Foundation and Hypothesis Development}

The purpose of sharing information is to provide additional knowledge to others. Whether sharing information is spontaneous or requested, the information shared will affect others (Hendrayati et al., 2020). The new generation of social networking sites has become the main platform for communication and interaction due to the widespread spread of the Internet. Its importance in today's society is also increasing due to the high volume of information that users get from it (Sun, 2020). Social media influencers (SMI), who represent a new type of independent third-party spokesperson, shape the attitudes of social media users through vlogs/blogs, and tweets (Korengkeng \& Tielung, 2018). Due to the persuasion and influence of SMIs, many companies and brands collaborate with them (Nimla-or, 2015). In this case, their presence should not be underestimated; it is important to understand what makes SMIs "influencers" and how they successfully use E-WoM as a platform to persuade consumers. Thus, SMIs are very helpful for consumers when getting useful product reviews. SMIs do not derive their influence from associations with certain brands. They just have an online persona that others trust and respect. In addition, previous research showed that several SMIs do not use their influence to promote and market products under a particular brand; most only provide honest and unbiased reviews, helping them earn consumers' trust (Rachmadi, 2020).

Wahyuningsih and Sukaatmadja, (2020) explains that a good brand image will be easily accepted by consumers from time to time to prove quality and meet buyer expectations. Brand is the company's ability to choose a name, logo, symbol, design package or attribute that is able to distinguish and identify products with competitors (Lubis \& Ariyanti, 2020). The ability of a brand to influence purchasing decisions is determined by the time it takes to prove how the product purchased by consumers is able to meet the expectations and needs of buyers (Hasmiati et al., 2020). Therefore, the brand must be built according to the time period and what values must be believed by the public as potential consumers (Irtanti, 2019). 
Based on the opinion above, it can be concluded that the definition of brand image is the result of consumer views or research on a brand is good or bad (Anggadwita, Alamanda, \& Ramadani, 2019). This is based on consideration or selection by comparing the differences found in several brands, so that the brand whose offerings meet the needs will be selected. A strong and positive image is one of the important things. Without a strong and positive image, it is very difficult for a company to attract new customers and retain existing ones. The right to a product's brand image will undoubtedly benefit consumers, as the brand image will influence the consumer's evaluation of the competing brands. The impact of brand image on consumer purchasing decisions, attitudes, and behaviors is largely determined by the brand image. This is because brand image is linked to consumer trust in a company. Keller defines brand image as a consumer's perception of a brand that is stored in their memory. The hypothesis developed in this study is based on the relationship between brand image and purchase decision:

The Influence of Brand Image on Purchase Decision

H1: Brand Image Has a Significant Influence on Purchase Decisions

According to product quality, product quality implies that quality is the overall characteristics and properties of a product or service that affect its ability to satisfy expressed or implied needs. Product quality according to (Kotler, 2008) the ability of a product to demonstrate its functionality, this includes overall durability, reliability, accuracy, ease of operation, and product repair, and other product attributes. One aspect that is also considered by consumers in buying a product is also the price factor, where consumers often compare prices with other competitors whose products are also cheaper and not less competitive. The price of the product is the sum of all the values provided by the customer benefiting from owning or using the product or service (Laksmitasari \& Wandebori, 2017). Companies need to continue to improve the quality of products or services and provide product price variations because increasing product quality and product price variations can make consumers feel satisfied with the product or service they buy and will influence consumers to make repeat purchases (Tjiptono \& Chandra, 2011). Beauty vloggers are currently gaining popularity at a rapid pace. Since the inception of the IndoBeauty Vlogger community, the number has increased fivefold from the previous year. According to previous research, beauty vloggers have a positive impact on customer purchasing decisions. As a result, here's how the hypothesis came to be:

The Influence of a Beauty Vlogger on Buying Decisions

$\mathrm{H} 2$ : Beauty vlogger has a significant influence on purchasing decisions

Purchase decisions are actions taken by consumers to choose one of several alternative choices in buying a product in the form of goods or services. In purchasing decisions, every consumer has a strategy to get a superior product that suits his satisfaction and desire. According to (Kotler, 2008), Buying decision is the process of all experiences in learning, choosing, using, and buying a product (Rayining \& Agung, 2019; Zhixuan, Hanchen, \& Feifan, 2019). According to Kotler in 2002 consumers have a sense of interest to buy a product offered by the company. Several supporting factors for the product, such as product quality, product model or variety, product convenience, prices that reach consumers, effective and efficient promotional activities, and activation factors for the company's product variations, all influence this. The findings indicate that product quality factors have a significant impact on purchasing decisions. This means that the higher the product's quality, the more likely it is to influence purchasing decisions. According to previous research, product quality has a positive influence on customer purchase decisions. As a result, here's how the hypothesis came to be: 
The Influence of Product Quality on Purchase Decisions

$\mathrm{H}_{3}$ : Product Quality Significantly Affects Purchase Decisions

\section{RESEARCH METHODOLOGY}

\section{Analysis of Method}

Based on the problem formulation and research objectives that have been described above, the form of this research is explanatory research (explanation), which is a study that aims to strengthen or reject theories and hypotheses from existing research. This study uses quantitative methods that can be tested and measured using statistics. The research in this study was conducted in Indonesia. The object of this research is a woman who uses Lipstick products. This study was conducted for approximately 2 months, and this study was conducted to examine the relationship between Beauty vlogger, brand image and product quality on purchasing decisions. In this study, to obtain data from respondents, it was done by distributing an online questionnaire in the form of a google form to consumers who had purchased Lipstick products.

Reseearch population is a generalization area consisting of objects or subjects that have certain qualities and characteristics determined by researchers to be studied and then drawn conclusions. The population of this study is the woman who have used or are currently using Lipstick products. The sample uses a purposive sampling method, which is a technique that does not provide equal opportunities for all populations to be sampled, but there are special criteria or characteristics that are met so that the sample is in accordance with the research objectives. The following criteria must be possessed by the sample in this study:

1. People who live in Indonesia

2. Female gender

3. Knowing about Beauty vlogger

4. Respondents aged 17 years and over

Thus the respondents who will be taken amounted to 100 respondents. The number of respondents is considered sufficient to represent the population to be studied.

\section{Descriptive Statistic Analysis}

Descriptive statistics is a data analysis technique used to describe the condition of research variables (Widodo, 2018), This descriptive statistical test is used to provide an overview and description of data so that it is contextually easy to understand by the reader.

\section{Multiple Linear Regression Analysis}

The data collected will be processed in stages to determine whether the proposed hypothesis is supported. Multiple regression analysis is used in this study to ascertain the direction of the relationship between the independent and dependent variables, to determine whether each independent variable is positively or negatively related to the dependent variable, and to forecast the value of the dependent variable as the independent variable's value increases or decreases.

The general formula for multiple linear regression is as follows:

Remarks :

$$
\mathbf{Y}=\mathbf{a}+\beta 1 \mathbf{X}_{1}+\beta 2 \mathbf{X}_{2}+\beta 3 \mathbf{X}_{3}+e
$$

$\mathrm{Y}=$ Purchase Decision

$\beta_{1}, \beta_{2}, \beta_{3}=$ Regression Coefficient

$\mathrm{X}_{1}=$ Beauty vlogger

$X_{2}=$ Brand Image

$X_{3}=$ Product Quality 


\section{Hypothesis Testing}

\section{Coefficient of determination test (R2)}

A hypothesis is an assumption or assumption that may be true and is often used as a basis for making decisions or used as a reference for further research. In hypothesis testing relates to the acceptance or rejection of a hypothesis under study. In this study using one of the statistical test tools, namely parametric statistical testing. Parameter testing was carried out with the determination of the null hypothesis $(\mathrm{HO})$ and the alternative hypothesis $(\mathrm{Ha})$ for testing the significant level.

\section{F Statistic test}

The F statistic test aims to test the feasibility of the specific model and is used to determine whether the independent variables jointly affect the dependent variable. The $\mathrm{F}$ test basically shows whether all the independent variables in the model have a joint effect on the dependent variable. In addition, the $\mathrm{F}$ test can be used to see if the regression model used is significant or not, provided that if the $p$ value $<(\alpha)=0.05$ and $f$ count $>f$ table, it means that the model is significant and can be used to test the hypothesis. With the level of confidence for hypothesis testing is $95 \%$ or $(5 \%)=0.05$.

\section{T . Statistical Test}

This test was conducted to determine the significant relationship of each independent variable to the dependent variable partially. Namely looking for whether or not there is an influence between company size and profitability on purchasing decisions partially. Assuming that if the t-count is significant, which can be seen from the regression analysis, it is smaller than $=5 \%$, it means that the independent variable has an effect on the dependent variable.

\section{DISCUSSION}

\section{Descriptive statistic analysis}

The data used in this study is primary data obtained from questionnaire data. This data includes variables Beauty Vlogger, Brand Image and Product Quality on Purchase Decisions. The data presented in the table is obtained from the results of processing the questionnaire using the IBM Statistics SPSS 25 program by looking at the frequency of answers given by the respondents. In this study, the description of respondents' responses is based on descriptive statistical tests which include the mean and standard deviation.

Tabel 1

Descriptive Statistics

\begin{tabular}{lccccc}
\hline $\begin{array}{l}\text { Research } \\
\text { Variable }\end{array}$ & N & Minimum & Maximum & Mean & $\begin{array}{c}\text { Standard } \\
\text { Deviation }\end{array}$ \\
\hline $\begin{array}{l}\text { Beauty } \\
\text { Vlogger }\end{array}$ & 100 & 14 & 24 & 19,10 & 2,149 \\
$\begin{array}{l}\text { Brand Image } \\
\begin{array}{l}\text { Product } \\
\text { Quality }\end{array}\end{array}$ & 100 & 15 & 25 & 19,04 & 2,098 \\
$\begin{array}{l}\text { Purchasing } \\
\text { Decision }\end{array}$ & 100 & 15 & 23 & 18,66 & 1,965 \\
\hline
\end{tabular}

Based on Table 1, it can be seen that for the Beauty Vlogger variable the mean value is 19.10 and the standard deviation value is 2.149 for the Brand Image variable, the mean value is 19.04 and the standard deviation value is 2.098 for the Product Quality variable, the mean value is is 18.66 and the standard deviation value is 1.965 and for the Purchase Decision variable the mean value is 19.33 and the standard deviation value is 2.323 . 
Tabel 2

Reliability Test Results

\begin{tabular}{|c|c|c|c|}
\hline Variable & $\begin{array}{l}\text { Cronbach Alpha } \\
\text { Value }\end{array}$ & $\begin{array}{l}\text { Cronbach } \\
\text { Alpha }\end{array}$ & $\begin{array}{c}\text { Cronbach Alpha > Value } \\
\text { Cronbach Alpha }\end{array}$ \\
\hline Beauty vlogger & 0,60 & 0,609 & Reliable \\
\hline Brand Image & 0,60 & 0,666 & Reliable \\
\hline Product Quality & 0,60 & 0,623 & Reliable \\
\hline Purchasing Decision & 0,60 & 0,694 & Reliable \\
\hline
\end{tabular}

Based on the results of the reliability test in Table 2, it can be seen that all of the cronbach's alpha values for each variable are (0.609), (0.666), (0.623), (0.694) where the cronbach's alpha value of each variable is greater than 0.60 this shows that the data in this study are reliable.

Tabel 3

Normality Test Results

\begin{tabular}{llr}
\hline & Mean & $\begin{array}{r}\text { Unstandardized } \\
\text { Residual }\end{array}$ \\
\hline $\mathrm{N}$ & Std. Deviation & 100 \\
Normal Parameters & , 0000000 \\
& Absolute & 1,47363935 \\
Most Extreme Differences & Positive &, 065 \\
& Negative &, 065 \\
Kolmogorov-Smirnov Z & &,- 059 \\
Asymp. Sig. (2-tailed) & &, 065 \\
\hline
\end{tabular}

Based on the test results in Table 3, it can be seen that the value of Asymp Sig. (2tailed) is worth more than 0.05 , which is 0.200 . This means that the residual data in this study is normally distributed.

Tabel 4

Hasil Uji Multikolonieritas

\begin{tabular}{lrr}
\hline \multirow{2}{*}{ Model } & \multicolumn{2}{c}{ Collinearity Statistics } \\
\cline { 2 - 3 } & Tolerance & \multicolumn{1}{c}{ VIF } \\
\hline Beauty vlogger &, 194 & 5,162 \\
Brand Image &, 157 & 6,355 \\
Product Quality &, 145 & 6,878 \\
\hline
\end{tabular}

Based on the results of the Multicollinearity Test in Table 4, it can be seen that the Variance Inflation Factor (VIF) value obtained from the data processing results is $>10$ so it can be concluded that there is no correlation between the independent variables and the regression model meets the multicollinearity assumption. 
Tabel 5

Heteroscedasticity Test Results

\begin{tabular}{|c|c|c|c|c|c|c|}
\hline & \multirow[t]{2}{*}{ Model } & \multicolumn{2}{|c|}{$\begin{array}{l}\text { Unstandardized } \\
\text { Coefficients }\end{array}$} & \multirow{2}{*}{$\begin{array}{c}\text { Standardized } \\
\text { Coefficients }\end{array}$} & \multirow[t]{2}{*}{$\mathbf{T}$} & \multirow[t]{2}{*}{ Sig. } \\
\hline & & B & Std. Error & & & \\
\hline \multirow{4}{*}{1} & (Constant) & 4,474 & ,747 & & 5.988 & ,000 \\
\hline & Beauty vlogger &,- 014 & , 082 &,- 037 & -176 & 861 \\
\hline & Brand Image &,- 007 & ,093 & ,017 & ,073 & 942 \\
\hline & Product Quality &,- 167 & 103 &,- 394 & -1.617 & 109 \\
\hline
\end{tabular}

a. Dependent Variable: ABRESID

Based on Table 5, the significance value of the Beauty vlogger variable is 0.861 , which is greater than 0.05 , which means that there is no heteroscedasticity in the beauty vlogger variable. The significance value of the brand image variable is 0.942 , which is greater than 0.05 , which means that there is no heteroscedasticity in the brand image variable. The significance value of the product quality variable is 0.109 , which is greater than 0.05 , which means that there is no heteroscedasticity in the product quality variable.

Tabel 6

Autocorrelation Test Results

\begin{tabular}{|c|c|}
\hline \multicolumn{2}{|r|}{ Unstandardized Residual } \\
\hline & Unstandardized Residual \\
\hline Test Value $^{a}$ &,- 00891 \\
\hline Cases < Test Value & 50 \\
\hline Cases $>=$ Test Value & 50 \\
\hline Total Cases & 100 \\
\hline Number of Runs & 49 \\
\hline Z &,- 402 \\
\hline Asymp. Sig. (2-tailed) & 688 \\
\hline a. Median & \\
\hline
\end{tabular}

Based on Table 6. the Asymp value is known. Sig. (2-tailed) of $0.688>0.05$, it can be concluded that there is no autocorrelation symptom.

\section{Multiple Linear Regression Analysis}

Multiple regression analysis was used to determine how much influence the independent variables had, namely: Beauty vlogger (X1), Brand image (X2), and Product Quality (X3) on Purchase Decisions (Y) for Emina Cosmetics Lipstick Products. 


\section{Tabel 7}

Multiple Regression Analysis Results Coefficients ${ }^{a}$

\begin{tabular}{|c|c|c|c|c|c|}
\hline \multirow[t]{2}{*}{ Model } & \multicolumn{2}{|c|}{$\begin{array}{l}\text { Unstandardized } \\
\text { Coefficients }\end{array}$} & \multirow{2}{*}{$\begin{array}{c}\text { Standardized } \\
\text { Coefficients } \\
\text { Beta } \\
\end{array}$} & \multirow[t]{2}{*}{$\mathbf{T}$} & \multirow[t]{2}{*}{ Sig. } \\
\hline & B & Std. Error & & & \\
\hline (Constant) & 2,158 & 1,450 & & 1,488 & 140 \\
\hline Beauty Vlogger & ,230 & 159 & 213 & 1,445 & 152 \\
\hline & 260 & 181 & 235 & 1,440 & 153 \\
\hline Product Quality & ,419 & 201 & ,355 & 2,090 & ,039 \\
\hline
\end{tabular}

Tabel 8

Coefficient of Determination R2 Model Summary ${ }^{b}$

\begin{tabular}{lrrrr}
\hline Model & R & R Square & $\begin{array}{c}\text { Adjusted R } \\
\text { Square }\end{array}$ & $\begin{array}{c}\text { Std. Error of } \\
\text { the Estimate }\end{array}$ \\
\hline 1 &, $773^{\text {a }}$ &, 597 &, 585 & 1,496
\end{tabular}

Based on Table 8, the results of the model summary analysis show that the magnitude of $\mathrm{R}$ square is 0.597 or $59.7 \%$. This shows that the percentage contribution of the variable Beauty Vlogger, Brand Image, Product Quality to Purchase Decision is $59.7 \%$ while the remaining $40.3 \%$ is obtained by other variables not examined in this study.

Tabel 9

F Test Results (Simultaneous Test) ANOVA

\begin{tabular}{lrrrrr}
\hline Model & $\begin{array}{l}\text { Sum of } \\
\text { Squares }\end{array}$ & Df & Mean Square & F & Sig. \\
\hline Regression & 319,120 & 3 & 106,373 & 47,499 &, $000^{\text {b }}$ \\
Residual & 214,990 & 96 & 2,239 & & \\
Total & 534,110 & 99 & & & \\
\hline
\end{tabular}

Based on the data in Table 9, it can be seen that the calculated $F$ is 47.499 with a significance level of 0.000 which is smaller than the 0.05 significance level. Thus, all independent variables $(\mathrm{X})$ simultaneously have an effect on the Purchase Decision.

Tabel 10

$T$ Test Results Coefficients ${ }^{a}$

\begin{tabular}{lrrrrrr}
\hline \multirow{2}{*}{ Model } & \multicolumn{2}{c}{$\begin{array}{c}\text { Unstandardized } \\
\text { Coefficients }\end{array}$} & $\begin{array}{c}\text { Standardized } \\
\text { Coefficients }\end{array}$ & & T & \multirow{2}{*}{ Sig. } \\
\cline { 2 - 4 } & \multicolumn{1}{c}{ B } & \multicolumn{1}{c}{ Std. Error } & \multicolumn{1}{c}{ Beta } & & \\
\hline (Constant) & 2,158 & 1,450 & & 1,488 &, 140 \\
Beauty vlogger &, 230 &, 159 &, 213 & 1,445 &, 152 \\
Brand Image &, 260 &, 181 &, 235 & 1,440 &, 153 \\
Product Quality &, 419 &, 201 &, 355 & 2,090 & 0,39 \\
\hline
\end{tabular}




\section{DISCUSSION}

\section{Effect of Beauty Vlogger on Purchase Decision}

The Beauty vlogger variable (X1) has a t-count value that is smaller than the t-table $(1.443<1.984)$ and its significance level is greater than $0.05(0.152>0.05)$. This shows that the Beauty vlogger variable partially has no significant effect on the Purchase Decision of Emina Cosmetics Lipstick Products. Respondents gave responses regarding each element of the Beauty vlogger variable that showed the average value of respondents is 3,82 which is included in the high category. The insignificance of Beauty vloggers on purchasing decisions can be explained by the phenomenon that some respondents admit they often watch Beauty vloggers reviewing Lipsticks online, but this can only be limited to bringing consumers to the stage of interest and most of them do not go to the stage of purchasing decisions. The results of this study are not in line with research conducted by (Lubis \& Ariyanti, 2020) which states that the Beauty vlogger variable has a significant influence on purchasing decisions. But the research is in line with the results of research conducted by (Nimla-or, 2015) which states that the Beauty vlogger variable does not have a significant effect on Purchase Decision. This contrary result are somehow showing that for lipstick product the existence of beauty vlogger are not needed since most of respondent on this research are a loyal customer of a lipstick product for a long term.

\section{The Influence of Brand Image on Purchase Decision}

The result are contrary to the result from (Irtanti, 2019) that stating brand image variable has significant influence toward purchasing decision. On the other hand, the result of this research are in line with the from (Wahyuningsih \& Sukaatmadja, 2020) that stating brand image has significant influence on purchasing decision.

\section{The Effect of Product Quality on Consumer Decisions}

The Brand Image (X1) variable has a t-count value that is smaller than the t-table $(1.440<1.984)$ and its significance level is greater than $0.05(0.153>0.05)$. This shows that the Brand Image variable partially does not have a significant effect on the Purchase Decision of Emina Cosmetic Lipstick Products. Respondents provide responses about each element of the Brand Image Variable that showed the average value of respondents is equal to 3.79 which is included in the high category. The insignificance of brand image to purchasing decisions is explained by the phenomenon that brand image cannot be an additional reference for potential consumers and becomes a consideration for the desired product. For consumers, a good brand image may not necessarily make them want to buy or try the product. The Emina brand has been widely known by the public and can be said to have a good brand image, so that people no longer consider it in making purchasing decisions. Some consumers consider other things, for example product quality, friend recommendations or according to their own wishes.

The product quality variable $(\mathrm{X} 3)$ has a t-count value that is greater than the $\mathrm{t}$-table $(2.090>1.984)$ and its significance level is less than $0.05(0.039<0.05)$. This shows that the Product Quality variable partially has a significant effect on the Purchase Decision of Emina Cosmetics Lipstick Products, or in other words the hypothesis $\mathrm{HO}$ is rejected, $\mathrm{H} 1$ is accepted. The results of this study explain that partially, product quality has a significant effect on purchasing decisions for Emina Cosmetics Lipstick Products. The results of this study are in line with research conducted by (Laksmitasari \& Wandebori, 2017) which shows that the Product Quality variable has a positive and significant influence on the Purchase Decision variable.

\section{CONCLUSIONS}

The findings show that beauty vloggers have no significant influence on Lipstick Product purchases in Indonesia. The lack of influence of beauty vloggers on purchasing decisions can be explained by the fact that some respondents admit to watching beauty 
vloggers review lipsticks online on a regular basis, but this can only be done online. Because not all consumers match the results of the beauty vlogger's review, and the majority of them do not proceed to the buying decision stage, it is only limited to bringing consumers to the interest stage. Meanwhile, in Indonesia, brand image has no significant impact on purchasing decisions for Lipstick Products. Consumers may not want to buy or try a product just because it has a good brand image. The Emina brand is well-known among the general public and has a positive brand image, so people no longer consider it when making purchasing decisions. Some consumers are more concerned with other factors, such as the product's quality; if the product's quality is satisfactory, they will almost certainly decide to purchase it; friends' recommendations are also likely to influence a consumer's decision to purchase a product.

In the meantime, in Indonesia, product quality has a significant impact on purchasing decisions for Lipstick Products. As a result, the Product Quality variable plays an important role in making Lipstick Product purchasing decisions. This study is still limited to a small area, so if you want to replicate it in a different setting, you'll need to re-test it. Meanwhile, cosmetic companies must gain a better understanding of their customers' characteristics, as well as what they need and want, so that Lipstick can better reflect their image in the future. As a result, the company will have an easier time attracting customers to purchase Lipstick products.

\section{REFERENCES}

Anggadwita, G., Alamanda, D. T. and Ramadani, V. (2019) 'Halal Label vs Product Quality in Halal Cosmetic Purchasing Decisions', IKONOMIKA, 4(2), pp. 227-242.

Armstrong, G., Kotler, P. and Da Silva, G. (2006) Marketing: An Introduction: An Asian Perspective. Pearson/Prentice Hall.

Dhestantya, D., Nesia, A. and Restu, U. (2018) 'Pengaruh Beauty Vlogger Suhay Salim Terhadap Keputusan Pembelian Wardah (Studi Survey pada Mahasiswi FISIP Untirta 2015)'. Universitas Sultan Ageng Tirtayasa.

Hasmiati, H. et al. (2020) 'The Effect of Brand Image and Price on Product Purchase Decisions at the Sewing House Akkhwat Makassar', Pinisi Business Administration Review, 2(2), pp. 57-68.

Hendrayati, H. et al. (2020) 'Online reviews by beauty vloggers and its impact on buying interest', in Advances in Business, Management and Entrepreneurship: Proceedings of the 3rd Global Conference on Business Management \& Entrepreneurship (GC-BME 3), 8 August 2018, Bandung, Indonesia. CRC Press, p. 226.

Irtanti, E. W. (2019) 'Pengaruh Kualitas Produk, Citra Merek dan Harga terhadap Keputusan Pembelian Produk Pixy Lip Cream: studi pada Mahasiswi UIN Sunan Ampel Surabaya'. UIN Sunan Ampel Surabaya.

Kotler, P. (2008) Test Item File [to Accompany] Principles of Marketing, [by] Philip Kotler, Gary Armstrong. Pearson Prentice Hall.

Laksmitasari, D. and Wandebori, H. (2017) 'The effect of local lipstick's packaging elements towards consumer perception and purchasing intention", in International Research Conference on Management and Business, pp. 1-8.

Lubis, N. C. and Ariyanti, M. (2020) 'Effect of celebrity endorsement, EWOM and brand image on purchase decision of Nature Republic products in Indonesia', in Managing Learning Organization in Industry 4.0: Proceedings of the International Seminar and Conference on Learning Organization (ISCLO 2019), Bandung, Indonesia, October 9-10, 2019. Routledge, p. 22.

Nimla-or, P. (2015) Influence of beauty bloggers on the purchase decision for cosmetic producs by Thai women. Faculty of Commerce and Accountancy, Thammasat University.

Rachmadi, K. R. (2020) 'Pengaruh vlogger review sebagai celebrity endorser terhadap purchase intention dengan brand image sebagai intervening variabel pada produk kosmetik dan perawatan wajah', Jurnal IImu Manajemen (JIMMU), 3(2), pp. 148-158. 
Rayining, S. P. and Agung, Y. (2019) 'THE INFLUENCE OF CELEBRITY ENDORSEMENT ON PURCHASE INTENTION OF WARDAH LIPSTICK PRODUCTS THROUGH BRAND IMAGE AND BRAND CREDIBILITY', Russian Journal of Agricultural and Socio-Economic Sciences, 90(6).

Saputri, D. A. and Setyawati, H. A. (2020) 'Analisis Pengaruh Beauty Vlogger Sebagai Reference Group, Lifestyle dan Brand Image Terhadap Keputusan Pembelian Lipstik Pixy', Jurnal IImiah Mahasiswa Manajemen, Bisnis dan Akuntansi (JIMMBA), 2(5), pp. 788-801.

Sun, M. (2020) 'The role of microblog beauty celebrities recommendations on consumer purchasing behavior: Evidence from Chinese female college students'.

Tjiptono, F. and Chandra, G. (2011) Service, Quality \& Satisfaction Edisi. 3rd edn. Yogyakarta: Andi Publisher.

Wahyuningsih, G. A. D. and Sukaatmadja, I. P. G. (2020) 'The Effect of Brand Image, Product Quality, and Brand Trust on Maybelline Lipstick Customer Loyalty in Denpasar City', American Journal of Humanities and Social Sciences Research (AJHSSR), 4(1), pp. 407412.

Zhixuan, L., Hanchen, G. and Feifan, L. (2019) 'Analysis of influencing factors of Chinese female college students' lipstick purchasing decisions'. 